\title{
尿中分泌型 $\operatorname{IgA}$ に関する研究
}

\section{E. coli の尿路上皮細胞附着に対する分泌型 IgA の阻止作用について}

$\begin{array}{ccccc} & \text { 西 } & \text { 尾 } & & \text { 彰 } \\ \text { 柇幌医科大学泌尿器科学教室 } & \text { 熊 } & \text { 本 } & \text { 悦 } & \text { 明 } \\ (\text { (主任: 熊本悦明教授) } & \text { 広 } & \text { 瀬 } & \text { 嵩 } & \text { 興 }\end{array}$

\section{STUDIES ON URINARY SECRETORY IgA (SIgA)}

2. Studies on the Effect of SIgA on Adherence of E.coli to the Vesical Epithelial Cell

Akira Nishio, Takaoki Hirose and Yoshiaki Kumamoto

Department of Urology, Sapporo Medical College

(Director: Prof. Y. Kumamoto)

We studied the function of urinary SIgA on adherence of E. coli, isolated from acute simple cystitis, to the vesical epithelial cell and obtained the following results.

1) The number of E.coli, adhering to the vesical epithelial cells which were taken from healthy adult females, ranged from 4 to 33 per cell with a mean of 18 . When SIgA was added to $200 \mu \mathrm{g} / \mathrm{d}$ 1, the number of adhered E.coli decreased from 2 to 25 with a mean of 14 .

2) From 9 to 135 of E.coli adhered to the vesical epithelial cells, taken from patients with the history of lower urinary tract infection, and the bacteria easily adhered to cells taken from patients with recurrent episodes of lower urinary tract infection in the past. When SIgA was added, the number of E.coli adhering to the cells obviously decreased to 5 to 61 with a mean of 25 .

3) The relation between the real urinary SIgA levels and the experimental levels on adhesion suggested that the effective level of SIgA in urine might be near the non-infected urinary SIgA levels.

4) These results suggest that urinary SIgA might have a function of inhibiting invading bacteria from adhering to the urinary tract mucosa.

要旨: 尿中分泌型 IgA (SIgA) の感染防禦機構に抢ける機能を検討する目的で細菌が粘膜の上皮細胞に附着す る過程において SIgA がどのような作用を果たしているかを検討した。上皮細胞は膀胒洗滌で採取し，また細 菌は急性単純性膀脂炎の患者尿から分離した E. coli を用いた。 SIgA は健康成人女子尿から精製したものを 用いた，1）健康成人女子例では 1 個の上皮細胞に平均18個の E. coli が附着し, SIgA 添加 $(200 \mu \mathrm{g} / \mathrm{dl})$ に より平均14個に減少した（減少率：22\%)，2）下部尿路感染症の既往を有する女子例では平均44個の E. coli が附着し，既往頻度の高い例では E. coli 附着数が増加した. SIgA を添加した場合附着数は平均25個に減少 した（減少率：58\%）．3） 尿中 SIgA 濃度に対応させた試験管内 SIgA 濃度を用いた E. coli の附着阻止作 用の検討から, SIgA の E. coli 附着阻止作用の効果発現濃度は, 非感染時の尿中 SIgA 濃度附近にあること が推測された。

\section{緒 言}

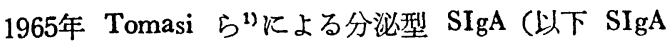
と略す）の発見とその後の研究により局所免疫に関する 知見は飛躍的な哭展を遂げ，現在では SIgA が外来から
侵入する微生物に対して重要な機能を果たしていること は多くの研究者が認めるところである，尿路感染症に特 いてもSIgA が感染菌に対して，特に下部尿路感染症に 蝚いて著明に反応していることは第 1 編2)にも述べた如 


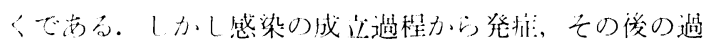
稆において SIgA が外们なる様式でどのような機能をも つているのかという具休们大検討は特に細菌感染症に拀 いてェしい.

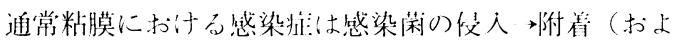

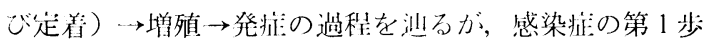
は侵人せる感染菌の粘膜面への附着であり，近年この器 に関する娭討が種々の触度からなされている゙3.

1972年 Williams ら“はい腙内の常体藏である Streptococcus が buccal cell に附着与る祭にSIgA が著明な

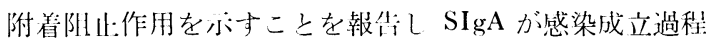
に打ける最も初期の段階でも感染防禦に関与している叮 能性を指摘した. その後 Parsons ら ${ }^{5) 6)}$ は膀胱において も粘膜上の分泌性の物質が间様の機能を有していること を報垈しているか， SIgA そのものについてい其体的店 娭討成績はふぶしていない。

そこで著者らは Williams らがぷした SIgAのは皮緗

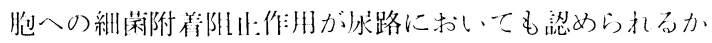

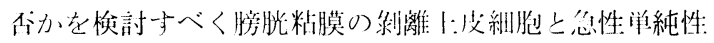
膀胱炎患者永から分離された E. coli を用いて契験を行 ない, 若トの知見を得たので報隼与る。

\section{対}

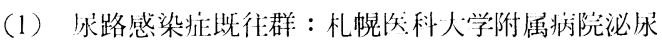
器科外来 (以卜当科外来之略す) で急性単純性膀腅炎の 洁潦を受け，治撩後 2 週閆以1:経過した26歳から77歳の 从子. 30例を対象とした。

（2）健康成人女子群：当科外来を受診した女子のう り異常が涩めら扎ず，目つ承路感染症の既往がない19藏 から61歳の从妨15例である。

\section{方 法}

Table 1 に亦す邚くGibbons ら"のうj法に準じた. 期 七总性単純性膀脱炎患者㽷加分離した E. coli（０148）を Tryptocase soy broth (BBL) で37 ${ }^{\circ} \mathrm{C}$, 昼夜培 差後 $\mathrm{pH} 7.3$ の燐酸緩衝液 (以下 PBS と略す) で 3 回 遠心洗滌し $10^{6} \mathrm{CFU} / \mathrm{ml}$ になる上らに調整した。…片膀 脱粘膜の1:皮細胞はネラトン・カテーテル（Fr 8) を 用いて牛理食塩水 $(50 \mathrm{ml})$ で膀胱洗滌を行ない採取後 PBS (pH 7.3) で800回転/分，10分間の遠心洗滌を3 1 回行ない， 1:支細胞数を $10^{4} \sim 10^{5}$ 湖 $/ \mathrm{ml}$ になるように 調整しそのの部を gram 染色してト皮細胞に細菌の 附着がないことを確かめた。次いで、皮細胞浮遊液 0.5 $\mathrm{ml}$ に種々の濃度の SIgA を $0.1 \mathrm{ml}$ または PBS ( $\mathrm{pH}$ 7.3）を $0.1 \mathrm{ml}$ 扰よ゙ E. coli 浮遊液 $0.4 \mathrm{ml}$ を加え総量!
Table 1 Schematic procedure of experiment.

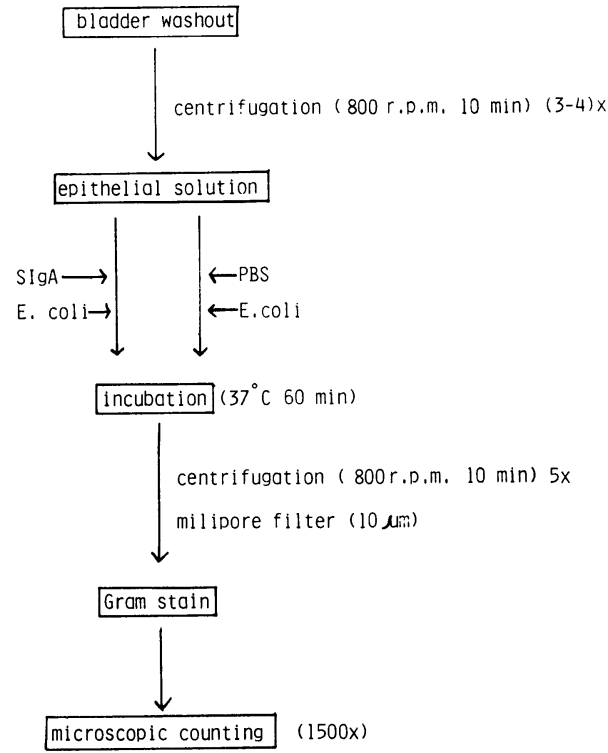

$1 \mathrm{ml}$ としてて艮く淑和した。次いでこの混公液を37 C， 60分開 incubate した.この後, PBS ( $\mathrm{pH} \mathrm{7.3)} \mathrm{で5|川|}$

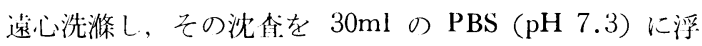
遊させて良く混和した後 $10 \mu \mathrm{m}$ の milipore filter を泊 した後 gram 染色し鏡検（1,500倍）した（Fig. 1).

上:皮細胞に附着した E. coli 数の算定は各ブレハラー トにつき50個の上皮細胞に附着した E. coli 数を数え， その头均值をもつて1個の1:皮細胞に対する E. coli 附 数とした.

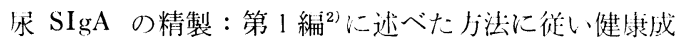
人从子㽷より精製した。

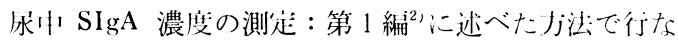
つた。

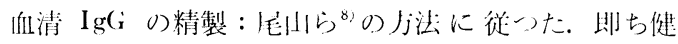

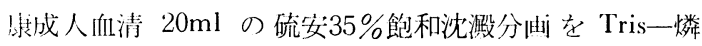

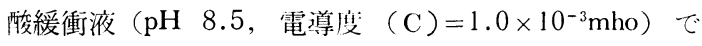
透析した後问緩衝液で斗衡化している DEAE-cellulose column $(2.0 \times 20 \mathrm{~cm})$ で溶出し, 最初の分曲を採取し た.

E. coli のO抗原の作成

Ebersole ら の)の法に従つた. 即ち E. coliを Trypto-

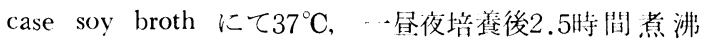
し, これを 1, 400g，15分間遠心した後その沈杳を95\% ethanol に溶解した。次いで37 C, 4 時满 incubate । 
Fig. 1 E. coli adhered to an epithelial cell taken from the bladder

1) light micrograph $(\times 1500)$

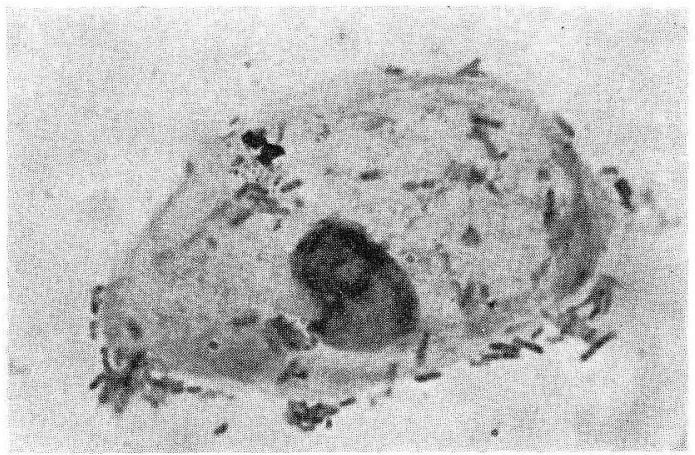

2) scanning electron micrograph $(\times 6000)$

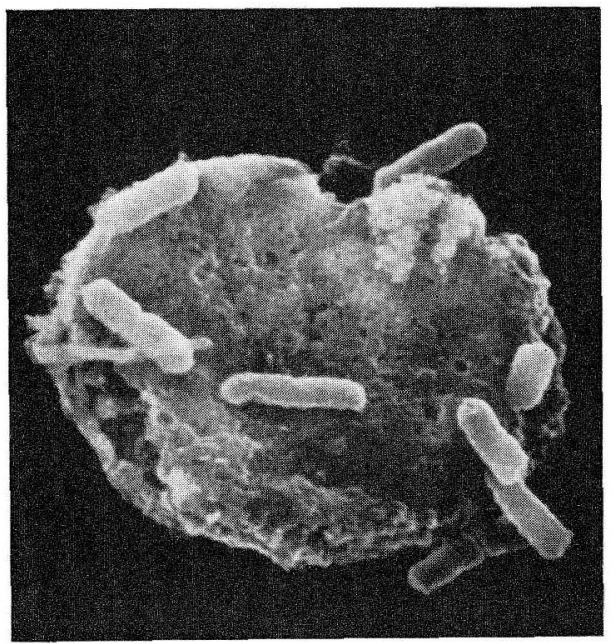

た後 $0.15 \mathrm{~N}$ 食塩水で 3 回洗滌しO抗原とした.

E. coli のH抗原の作成

Ebersole ら の)方法に従つた. E. coli 索 Tryptocase soy broth にて $37^{\circ} \mathrm{C}$, 一昼夜培養後 $1,400 \mathrm{~g}, 15$ 分間遠心 し, その沈査を PBS ( $\mathrm{pH}$ 7.2) で 3 回遠心洗涤し, 再 び同液に溶解した。 これを10\%フォルマリン緩衝液にて $0.5 \%$ フルマリン濃度に調整し， $37^{\circ} \mathrm{C}, 18$ 時間 incubate した後再び 3 回洗深してH抗原とした。

細菌凝集反応

Ebersole ら ${ }^{9)}$ の方法に従つた. 即ち健康成人尿より精 製した SIgA の $2,000 \mu \mathrm{g} / \mathrm{dl}$ わら $0.95 \mu \mathrm{g} / \mathrm{dl}$ 采で倍数稀 釈系列の各 $0.05 \mathrm{ml}$ と $\mathrm{O}$ 抗原あるいはH抗原 $0.02 \mathrm{ml}$ を 良く混和し， $37^{\circ} \mathrm{C}, 2$ 時間 incubate した後 $4{ }^{\circ} \mathrm{C} に$
$6 \sim 8$ 時間静置し凝集の有無在判定した.

間接赤血球凝集反応

木村ら ${ }^{10)}$ の方法に従つた. 即ちタンニン酸処理緬羊赤 血球を E. coli のO抗原和よびH抗原を用いて感作し， 杂た SIgA は緛羊赤血球で吸収したウサギ血清を用いて $2,000 \mu \mathrm{g} / \mathrm{dl}$ から $0.95 \mu \mathrm{g} / \mathrm{dl}$ まで倍数稀採した。次いで 抗原感作緬羊赤血球液 $0.05 \mathrm{ml}$ と各濃度の SIgA $0.5 \mathrm{ml}$ を良く混和し，室温にて12時間静置後㠜集の有無を判定 Uた.

\section{結＼cjkstart果}

\section{(1) 予偳奏験}

1) SIgA の E. coli $(0-148)$ に対する特異性につ W.

今回の実験に供した E. coli のH抗原执よびO抗原と SIgA の間には細菌凝集反応および間接赤血球凝集反応

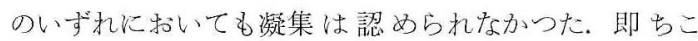
れらの成績で放る限りでは今回用いた SIgA は E.coli (O-148) に対して特異的抗体活性は有していないと 判断される。

2）E.coli の上皮細胞への附着における条件につい $\tau$

a) PBS の $\mathrm{pH}$ 及び incubation time が上皮細胞に及 ぼす影響について

上皮細胞は健康成人女子から採取したものを使用し， 事た上皮細胞の生死の判定は King $ら^{11)}$ の方法に従い， $0.01 \%$ trypan blue 液の上皮細胞核内八の浸透状態から 判断した. pH 6.0 の PBS を使用した際の生上皮細胞 の推移を Fig. 2-a に示した. 調整時の生上皮細胞数 を100\%とすると60分間 incubate した際の生上支細胞率

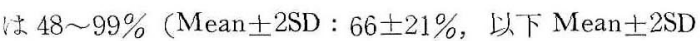
は省略)，120分間では36〜 59\% (47士18\%) であつた.

pH 6.5 の PBS 老使用した場合は Fig. 2-b に示与 如く，60分間の incubation では49〜103\% (78土22\%),

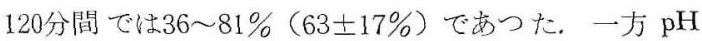
7.3 の PBS では Fig. 2-c K示す如く60分間の incubation では73〜108\% (93土15\%)，120分間では49〜83\% (72士14\%) であつた. 以上の成績から上皮細胞の状態 を良好に保つには $\mathrm{pH} 7.3$ の $\mathrm{PBS}$ が良く，末た $\mathrm{pH}$ が 下がるに伴ない死上皮細胞率が上昇すると判断された。 推計学的には $\mathrm{pH} 6.0$ と $\mathrm{pH} 6.5$ および $\mathrm{pH} 7.3$ の間 に有意の差が認められた。

また incubationについてはその時間が長くなるに伴 ない生上皮細胞率の低下が認められた。 
Fig. 2-a Effect of $\mathrm{pH}$ of phosphate buffered solution and incubation time on the number of bacteria adhered to an epithelial cell.

$$
\text { pH } 6.0
$$

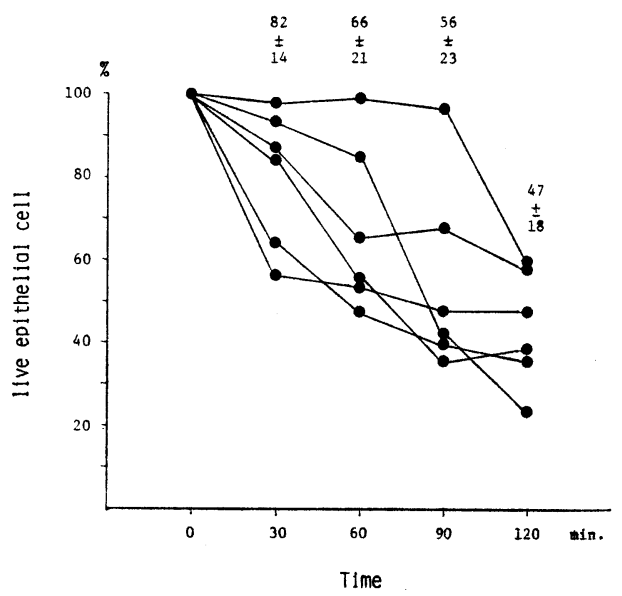

Fig. 2-b

PH 6.5

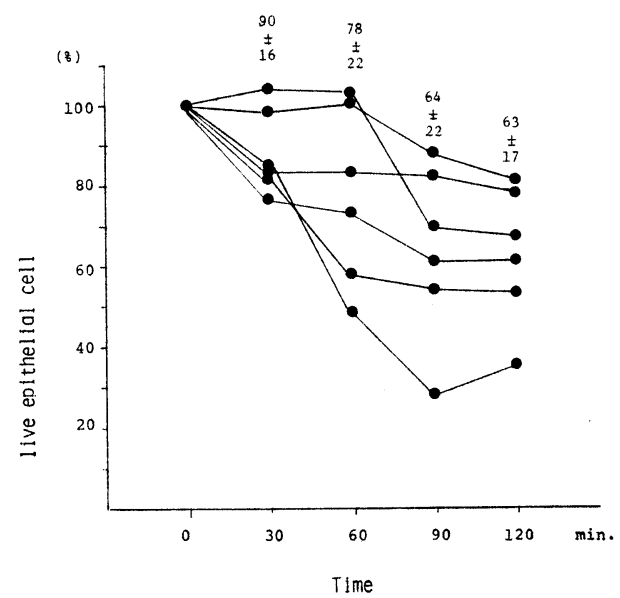

b) 細菌の前培養時間および incubation time が細菌附 着に及ぼす影響について

対数増殖期にある E. coli (8時間培養) と静止期に ある E. coli (18〜20時間培養) の附着能を検討する目 的で 5 例の健康成人女子から採取した上皮細胞を用いて 行なつた。

Fig. 3 に成績を示したが，両群間には有意の差を認
Fig. 2-c

PH 7.3

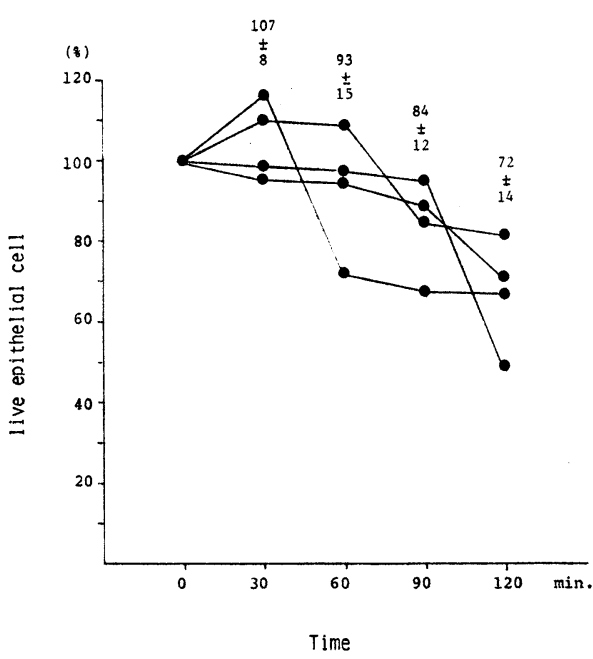

Fig. 3 Effect of cultured time of E. coli and incubation time on the number of bacteria adhered to an epithelial cell.
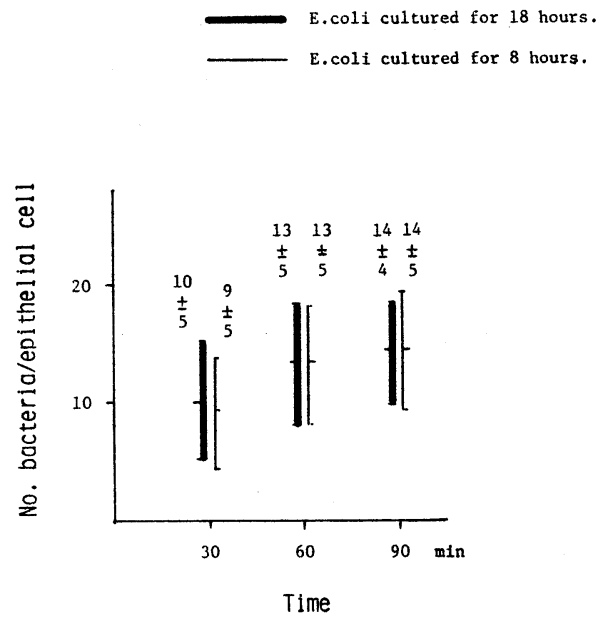

めなかつた. また incubation time と E. coli 附着数の 関係についてみると 30 分と60分あるいは90分間に有意の 差が認められた。
(II) 本実験
(1) 健康成人女子群

1） SIgA 非添加時の E. coli 附着数について

a）日差変動 
4 例について異なつた日に上皮細胞を 3 回採取して E. coli の附着数の変動を検討した.

Fig. 4 に示す如く第 1 回目は6〜27個（17士10個〉,

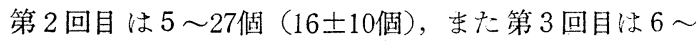
24 個（15士7 個）であり，各例の変動の幅は $6 \sim 21 \%$ (14士7\%)であった。

Fig. 4 Changes in the number of bacteria adhered to an epithelial cell taken from the normal controls on a different day.

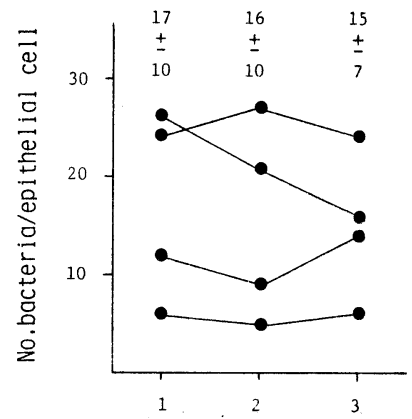

time

b) 健康成人女子群の附着数

15例の E. coli 附着数は 4 ３3個（平均18個），5\% の危険率で棄却限界を求めて正常範囲とすると 7 29個 であつた．これを年代別にみると Fig. 5 の如く年代が 高くなるに伴ない附着数もやや増加する傾向が認められ た.

Fig. 5 Relation between age and the number of bacteria adhered to an epithelial cell in normal controls.

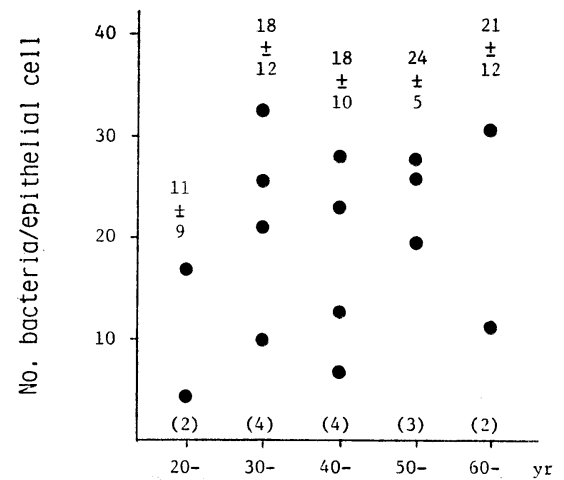

Age
2） SIgA 添加時の附着数について

a) SIgA 濃度の附着に及ぼす影響について

7 例から採取した上皮細胞の浮遊液に SIgA を添加し SIgA の影響について検討した。

上皮細胞，E. coli 祘よび SIgA 混合液の SIgA 濃度

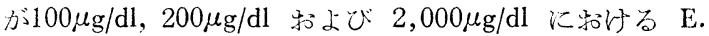
coli 附着数の変化を検討した成績を Fig. 6 亿示した. SIgA 非添加時の附着数は 6 〜 37個（22士11個）で沙る が，SIgA 濃度が $100 \mu \mathrm{g} / \mathrm{dl}$ の場合には附着数は 6 〜 37 個

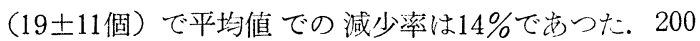
$\mu \mathrm{g} / \mathrm{dl}$ の場合には 6 27個（14士10個）で非添加時の附 着数に対する減少率は $38 \%$ であつた。一方 $2,000 \mu \mathrm{g} / \mathrm{dl}$ での附着数は 5 29個（14士9個）であり，平均值では $200 \mu \mathrm{g} / \mathrm{dl}$ での附着数と同值で㐫つた. 以上の成績を推 計学的汇処理すると $100 \mu \mathrm{g} / \mathrm{dl}$ と $200 \mu \mathrm{g} / \mathrm{dl}$ 峁るい法, $2,000 \mu \mathrm{g} / \mathrm{dl}$ の間で有意の差が認められたため，以後は $200 \mu \mathrm{g} / \mathrm{dl}$ 飞扝ける成績をもつて SIgA 添加時の附着数 とすることにした。

Fig. 6 Effect of SIgA concentration on the number of bacteria adhered to an epithelial cell in normal controls.

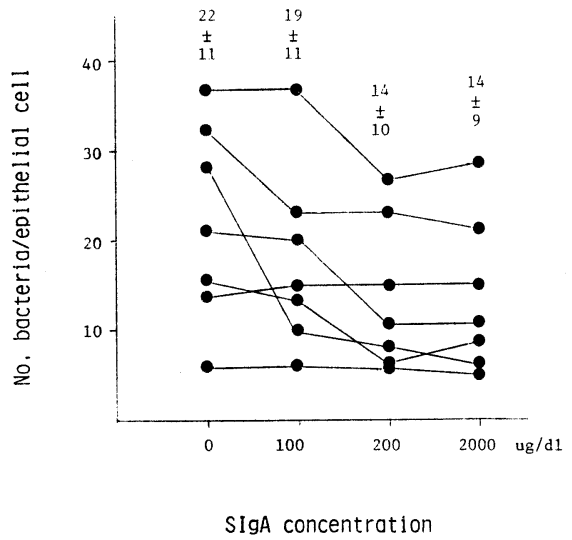

b) SIgA 添加 $(200 \mu \mathrm{g} / \mathrm{dl})$ 時の E. coli 附着数 SIgA 添加時の附着数は 2 25個（平均14個)，5\%の 危険率で棄却限界を求めて正常範囲とすると 5 ２3個で あつた。 またその減少率は平均 $22.0 \%$, 減少率の正常範 囲は4.4〜43.2\%であつた．年代別にみると Fig. 7 の如 くいずれの年代炕いても SIgA 添加により附着数の減 少が見られ，年代間の減少率の幅は11.2〜31.8\%で西つ た. 
Fig. 7 Relation among age, SIgA and the number of bacteria adhered to an epithelial cell in normal controls.

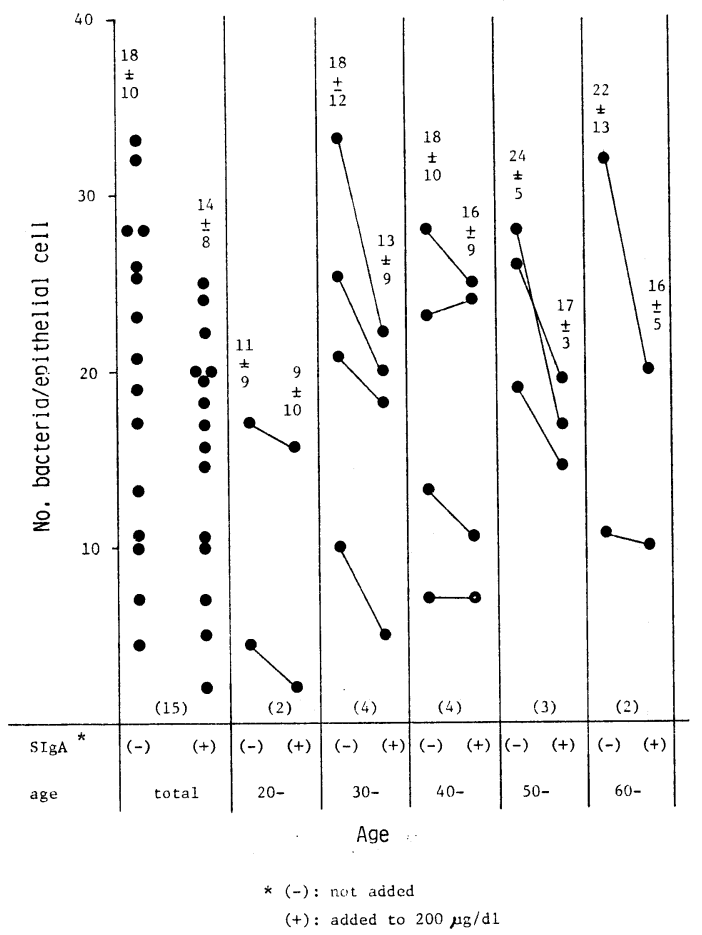

（2）尿路感染症（下部㽷路感染症）既往群

1) SIgA 非添加時の E. coli 附着数

本群 (急性単純性㔙脱炎の治癒後少なくとも2 週間以 上経過したもの）における附着数は 9 〜 132個（44士26 個）で健康成人女子の場合より有意に高く，徤康成人女 子に打いて求めた正常範四の附着数（7〜29個）を示し たものは30例中10例（33.3\%）のみであつた. また年代 別には Fig. 8 に示寸如く50藏代の例の附着数がやや少 ないものの年代と E. coli 附着数の間には特定の傾向は みられなかつた。

一方急性単純性膀胱炎の既往頻度の明らかで放つた 27例について 既往頻度と附着数の関係についてみると Fig. 9 に示す如く既往頻度が $0 \sim<1$ 回/年の群では

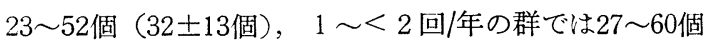

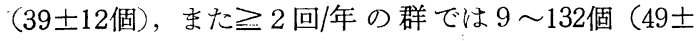
33個）となり，急性単純性膀胱炎の既往頻度が高くなる に伴ない E. coli 附着数が増加する傾向が認められ，特 に100個以上の極めて高い附着数を示した 2 例の既往頻 度はいずれもミ2 回/年であつた。
Fig. 8 Relation between age and the number of bacteria adhered to an epithelial cell in patients with past histories of lower urinary tract infections.

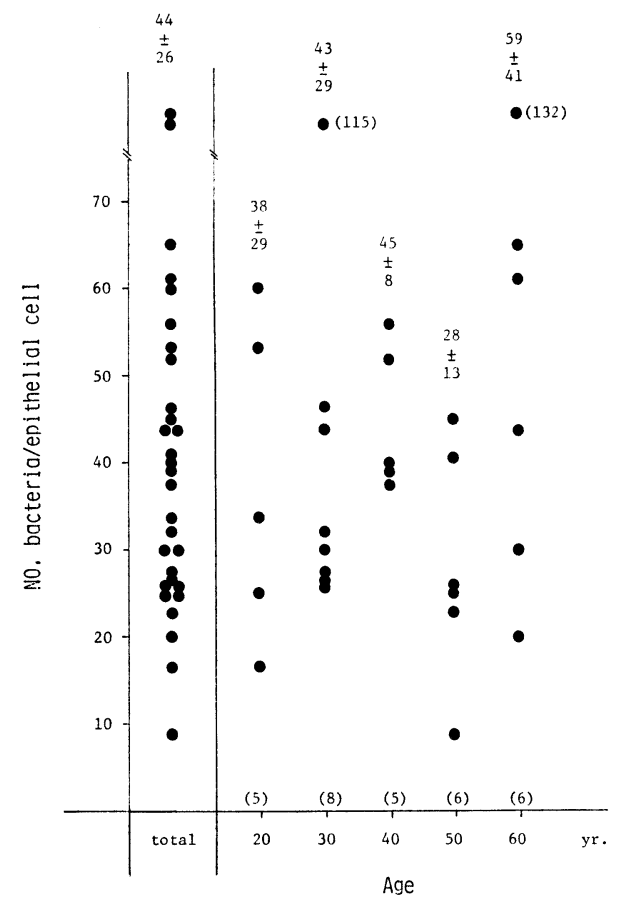

2) SIgA 添加 $(200 \mu \mathrm{g} / \mathrm{dl})$ 時の E. coli 附着数 $\mathrm{SgA}$ 添加時の附着数は 5〜61個（25士11個）で SIgA 非添加時と比較すると著明な減少がみられたが，健康成 人に持いて求められた SIgA 添加時の正常範囲の附着数 （5２3個）を示したものは 9 例 $(30.0 \%)$ であつた. この 5 ち SIgA 非添加時も正常範囲内であつたものは 6 例で他の 3 例は SIgA 添加によりはじめて正常範囲の 附着数を示したものである。

一方減少率は平均 $43.2 \%$ で市つたが，健康成人女子で 同様の検討をした前項（Fig. 7) の成績（減少率 : 22.0 \%)より著明に高かつた.な拉正常範囲の減少率（4.4〜 $43.2 \%$ )を示したものは30例中17例 $(56.7 \%)$, 正常範囲 をこえる減少率を示したものが11例 (36.7\%) みられた が，後者のらち 7 例は $50 \%$ 以上を示し最高減少率は 75.0 \%であつた。

SIgA 添加時の E. coli 附着数を年代別にみると Fig. 10 の如く40歳代（減少率：53.3\%）执よご60歳代（減 少率： $40.7 \%$ ）で著明な減少がみられた。

一方急性単純性膀脱炎の既往頻度との関連に打いてみ 
Fig. 9 Relation between frequency of episode and the number of bacteria adhered to an epithelial cell on patients with past histories of lower urinary tract infections.

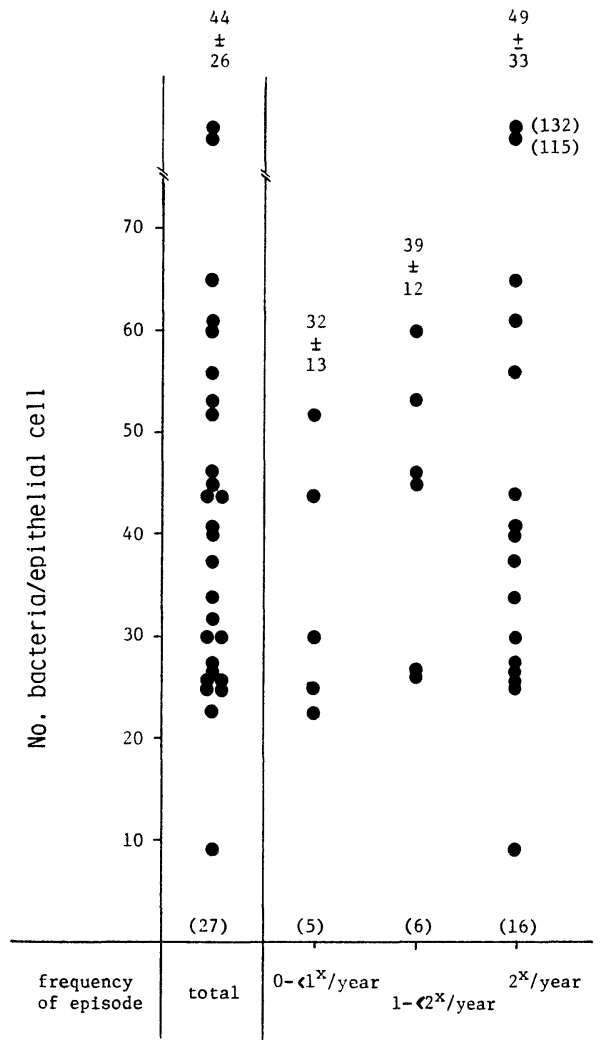

ると Fig. 11 の如く SIgA 添加時の E. coli 附着数は

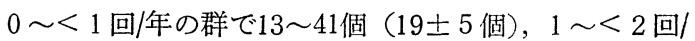

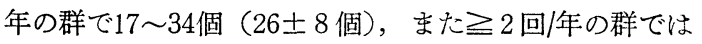
5 ６1個（28土14個）で㐫つた。これ觉減少率でみる と $0 \sim 1$ 回/年の群は $40.6 \%, 1 \sim<2$ 回/年の群は33.3 \%,またミ2 回/年の群では $42.9 \%$ で 3 群間に著明な差 はみられなかつた. しかし正常範囲をこえる減少率を示 したものは $0 \sim<1$ 回/年の群で 6 例中 1 例 (16.7\%), $1 \sim<2$ 回/年の群で 6 例中 2 例 $(33.3 \%)$, また 2 回/ 年の群では16例中 5 例 $(31.3 \%)$ となり後 2 者でやや高 い傾向がうかがわれた。

3） SIgA の E. coli 附着阻止作用の発現濃度に関す る検討

下部尿路感染症にて当科外来通院中の11例について非 感染時に膀胱粘膜の上皮細胞および尿を同時に採取して
Fig. 10 Relation between frequency of episode and the number of bacteria adhered to an epithelial cell in the patients with past histories of lower urinary tract infections.

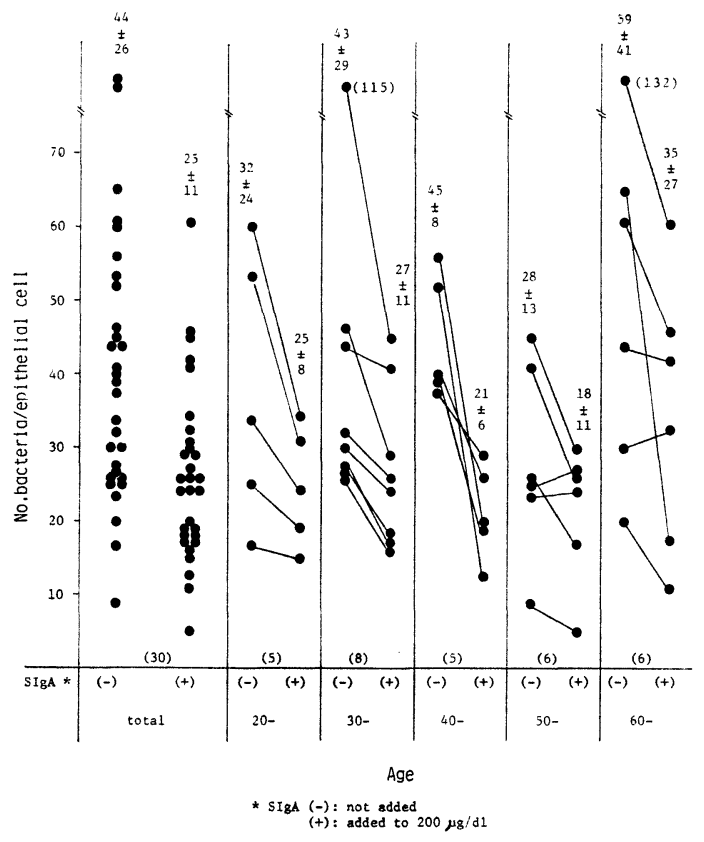

尿中 SIgA 濃度を測定し，これと試験管に作成した尿中 SIgA 相当濃度に拈ける E. coli の阻着阻止効果の関連 について検討した. 11例の年龄，尿中 SIgA 濃度，附着 実験に打けるSIgA 濃度および附着数は Table 2 に示し た.また Fig. 12 には実測尿中 SIgA 濃度を 0 〜 $<100$ $\mu \mathrm{g} / \mathrm{dl}, 100 \sim<20 \mu \mathrm{g} / \mathrm{dl}$, 打よび $200 \sim 300 \mu \mathrm{g} / \mathrm{dl}$ の 3 群 に分けて附着数の推移を示した（Fig. 12 中の（）内 数字は Table 2 の症例番号を示す). $0 \sim<100 \mu \mathrm{g} / \mathrm{dl}$ 群 では 4 例中 3 例は試験管内の $100 \mu \mathrm{g} / \mathrm{dl}$ 濃度で明らかに 附着数の減少をみた. $100 〜<200 \mu \mathrm{g} / \mathrm{dl}$ 群の 4 例では， 症例（8）は $100 \mu \mathrm{g} / \mathrm{dl}$ の濃度で附着数の減少がみられ， 症例（7）では $200 \mu \mathrm{g} / \mathrm{dl}$ で減少した. 一方 $200 \sim 300 \mu \mathrm{g} /$ dl の 3 例では, 症例 (11) は $200 \mu \mathrm{g} / \mathrm{dl}$ で, また症例 (10) は $300 \mu \mathrm{g} / \mathrm{dl}$ で各々附着数の減少傾向がみられ た.

以上の如く11例中 7 例 では試験管内での SIgA 濃度 が症例の尿中 SIgA 相当濃度前後で E. coli 附着阻止効 果が認められた。

以上の成績から判断すると, 尿中 SIgA の細菌附着阻 止作用の発現濃度は非感染時の尿中 SIgA 濃度附近にあ 
Fig. 11 Relation between the frequency of episode and the number of bacteria adhered to an epithelial cell in patients with past histories of lower urinary tract infections.

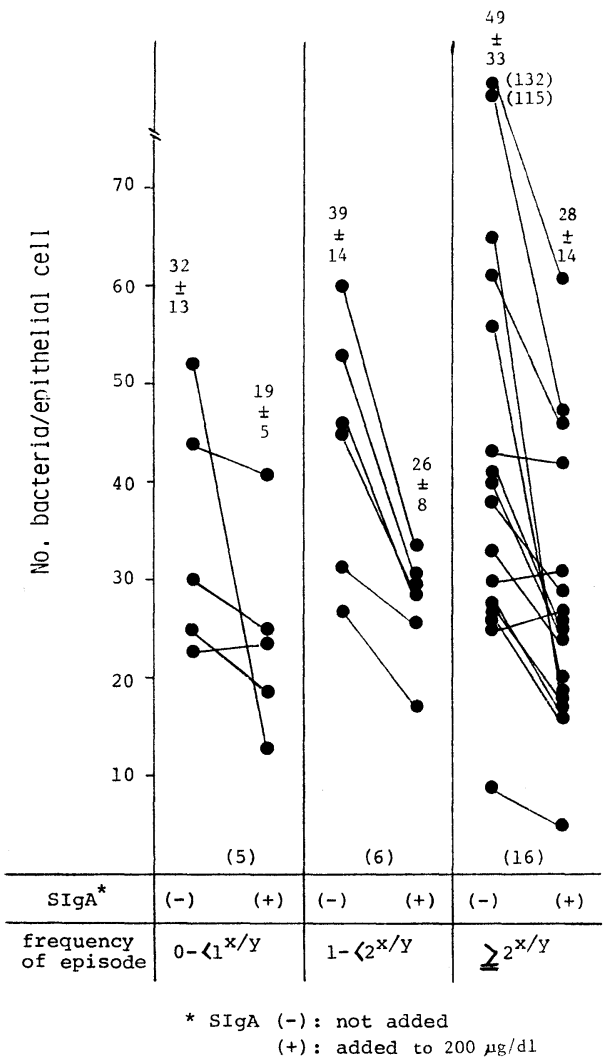

ることが推測された。

\section{考案}

SIgA の機能に関しては種々の点に执いて検討されて 来ているが末だ充分なる解明は得られていない.

South ${ }^{12)}$ は分泌性抗体に期待される性状として合目的 的論立場から次の 7 項目を挙げている.

1）粘膜表面の病原体に対して抗体活性を有している こと.

2）病原体が侵入するのを阻止し，その増殖を抑制す ること.しかし必ずしも殺菌的である必要はない。

3）粘膜表面で速やかに産生され分泌されること.

4）々の為の効果的な機構が存在すること.

5）粘膜面に附着する性状を有すること.

6）蛋白分解酵素に対して抵抗性を有し，末た $\mathrm{pH，}$ 温度, 塩濃度の変化により, その活性が障害されないこ
Table 2 Relation between urinary SIgA level and effect of experimental SIgA level on adherence

\begin{tabular}{c|c|c|c|c|c|c}
\hline \multicolumn{2}{c|}{} & \multicolumn{4}{|c}{$\begin{array}{c}\text { SIgA concentration in } \\
\text { vitro }(\mu \mathrm{g} / \mathrm{dl})\end{array}$} \\
\hline $\begin{array}{c}\text { Case } \\
\text { No. }\end{array}$ & Age & $\begin{array}{c}\text { urinary } \\
\text { SIgA level } \\
(\mu \mathrm{g} / \mathrm{dl})\end{array}$ & 0 & 100 & 200 & 300 \\
\hline 1 & 22 & 73.3 & 51 & 29 & 27 & 26 \\
\hline 2 & 41 & 72.0 & 32 & 22 & 20 & 21 \\
\hline 3 & 18 & 96.0 & 17 & 19 & 17 & 14 \\
\hline 4 & 27 & 60.0 & 36 & 12 & 10 & 11 \\
\hline 5 & 55 & 195.3 & 53 & 46 & 49 & 40 \\
\hline 6 & 19 & 161.2 & 31 & 27 & 27 & 22 \\
\hline 7 & 48 & 170.0 & 34 & 31 & 18 & 20 \\
\hline 8 & 49 & 103.5 & 42 & 16 & 12 & 9 \\
\hline 9 & 58 & 272.3 & 44 & 38 & 39 & 38 \\
\hline 10 & 37 & 227.3 & 38 & 41 & 33 & 28 \\
\hline 11 & 23 & 241.5 & 26 & 24 & 15 & 16 \\
\hline & & & & &
\end{tabular}

L.

7）補体系から独立していること.

確かに SIgA は上記のいくつかを満足させる性状を有 しているが，感染症に打ける SIgA の機能として明らか にされている点は少ない. 各種ウイルスに対する中和抗 体としての機能はその1つであり, 既に括びただしい数 の報告が見られる ${ }^{13) 14}$.

一方細菌感染症における機能については未だ不明の点 が多い. 少なく共細菌に対する直接的な抗菌作用は全く 見られない. しかし Burdon ら ${ }^{15)}$ は補体以外のある種の 血清成分との共存下では殺菌作用を認め，また Hill ${ }^{16)}$, Adenolfi ら ${ }^{17)}$ は補体执よび lysozyme との共存下では殺 菌作用が認められるとしている.

一方補体系との関連についてみると classical pathway を介した場合については，Ishizaka ら ${ }^{18)}$ はこれを否定し ているが，最近の Iida $^{19)}$ の報告によると SIgA は $\mathrm{C}_{1} \mathrm{q}$ との結合が可能であるとしている. Alternate pathway については既に Götze ら ${ }^{20)}$ が SIgA は $\mathrm{C}_{3}$ を活性化する と報告しているところであり，従つていずれの pathway を介しても complement-dependent bacteriolysis が機能 する可能性は推測し得るところである. Opsonin 作用に つては Wilson ${ }^{21)}$, Zipursky $5^{22)}$ が, ヒト初乳 SIgA で検討した成績はこれを否定するものでありまた Steele $\mathrm{e}^{23)}$ がマウスの腸液で検討した場合にも殆んど認ぬ 
Fig. 12 Relation between urinary SIgA level and the effect of SIgA concentration in vitro corresponding to urinary SIgA level on the number of bacteria adhered to an epithelial cell.

(A) $\quad 0-\langle 100 \mu g / d 1$

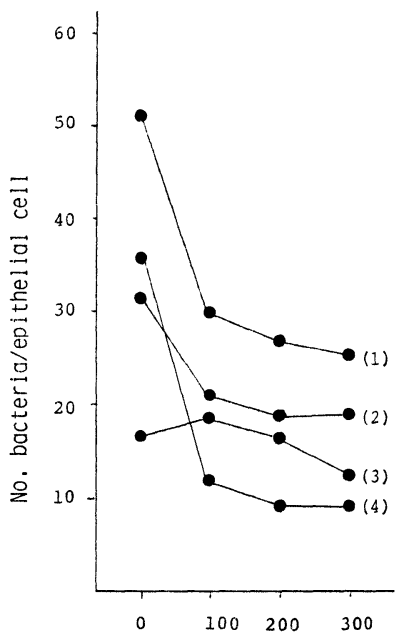

(B) $\quad 100-<200 \mu \mathrm{g} / \mathrm{dl}$

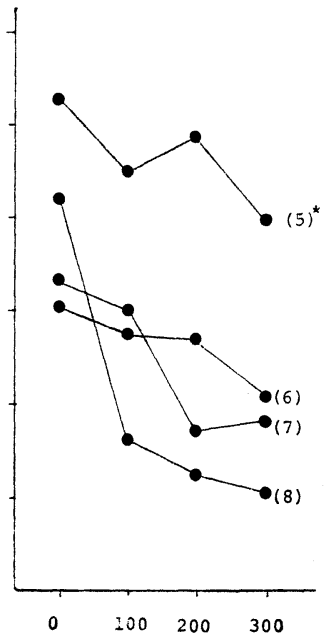

(C) $200-300 \mu \mathrm{g} / \mathrm{dl}$

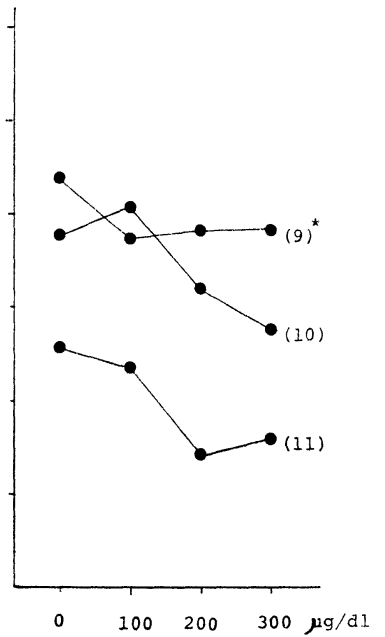

SIgA concentration

No. in (): Case number in table 2

Fig. 13 Effect of IgG on adherence in normal controls

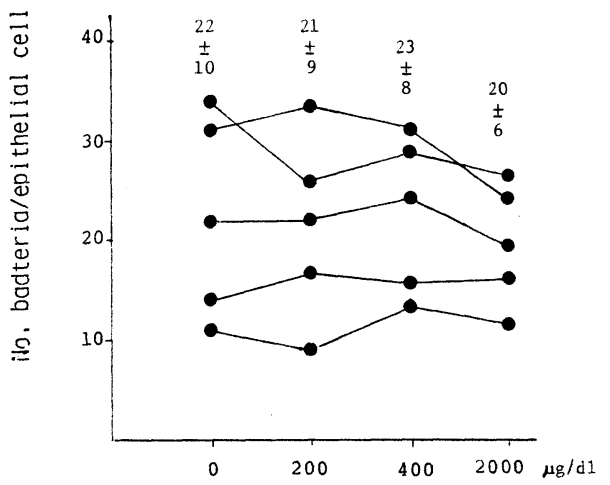

IgG concentration

ていない. しかし Wernet $5^{24)}$, Knop ら ${ }^{25)}$ が豚㧍よび 家鬼の初乳 SIgA を用いて検討した成績では opsonin 作 用を認めている。

従来の免疫グロブリンの機能は多くの場合血管内むる いは組織内の環境が前提で㐫ろう。従つて外分泌液内で 㙨能すると考光られるSIgA の場合には先の South ${ }^{12)} の$ 示した性状からもらかが党るようにその機能に沶いても 他の货疫グロブリンとは買なつたものを有していること
は充分推測されるところである。

1972年 Williams ら4は山腔内以常在与る5種の Streptococcus と buccal cell を in vitro で incubate した 際 Parotid saliva から精製した SIgA が Streptococcus の buccal cell への附着を著明に阻止することを認めた。 In vivo の実験では1969年 Freter ${ }^{26)}$ が家鬼の Vibrio cholerae (以下 V. cholerae と略す) の笑験腸管感染症に 执いて SIgA が主成分である coproantibody（糞便抗体） が，V. cholerae の腸管粘膜への附着を阻止する現象を 認め，その後 Fubura ら ${ }^{27) \& ~ V . ~ c h o l e r a e ~ て ゙ ー ウ ス を ~}$ 経口免狻した際の腸液中の SIgA が同様の作用を有する 成績を示している。

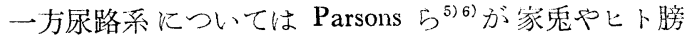
胱に沶いて粘膜表面に存在与る mucin (mucopolysaccharide) が細菌の粘膜への附着に対して著明な附着阻止 作用を有することを認め，同時にそれが分泌性のもので あろらと推測している. 現在までに得られている免疫組 織学的所見では SIgA は内腔の粘膜表面にも認められて おり，従つてこの mucin 厙内に SIgA が含まれている こと束推測される.

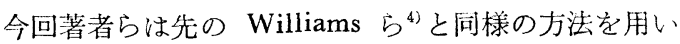
て SIgA の機能について検討した. 
Williams らの成績は Streptococcus と buccal cell と いら口腔内環境を前提としたものであるが，著者らは膀 胱粘膜の上皮細胞と急性単純性膀胱炎患者㲾から分離さ れた E. coli (O-148) を用いる尿路系の条件下で検討 を行なつた。

また契験構成因子の中で Williams らと置なる点は彼 らが口腙内常在菌である Streptococcus を用いたのに対 して著者らは急性単純性膀胱炎の感染菌を用いた点であ ๖.

さて今回得られた成績についてみると尿路感染症の成 立機作の観点から興味あるものが得られた。その1つは 健康成人女子比比較して急性単純性膀胱炎の既往を有す る女子の膀胱粘膜上皮細胞は今回用いた E. coli に対し て易附着性であることである. 健康成人女子の場合 1 個 の上皮細胞住附着与る E. coli は 4 33個（平均18個， 正常範囲： 7 29個）であるが，急性単純性膀胱炎の既 往を有する女子の場合には 9 132個（44士26個）であ り，明らかに附着数の増加が認められた，更にこれら症 例の年齢古るいは急性単純性膀胱炎の既往頻度との強い 関連傾向が認められた。

膀胱粘膜の上皮細胞を用いた成績は未だ少なく他の 成績との比較は困難であるが，Källenius $5^{28)}$, Fowler ら ${ }^{299}$ は periurethral cell を用いて著者らと同様の奏験を 行ない，尿路感染症に罹患し易い女子では健康女子に比 較してやはり細菌が著明に附着し易いことを認めてい る. また Parsons $5^{30)}$ も vaginal cell で同様の成績を 得ている.

現在では多くの場合尿路感染症の感染菌が外永道口 から逆行性に尿路に侵入することは定説化されている. 近年乞の bacterial source として periurethra 特よび vagina の colonization が重視され，これらの部位にお ける細菌の colonization 之尿路感染症の発症は強い関連 を有するとされている ${ }^{31}$. 従つて Källeniusら, Fowler ら，Parsons らの成績や著者らの得た成績から判断なる 之尿路感染症渻患し易い女子の場合には健康成人女子 に比較してょり容易に感染成立へと進む環境が準備され ていることが推測される.

一方 SIgA を添加した場合下部尿路感染症（急性単純 性膀脂炎) 既往群では附着数の減少が著明であつた. 即 ち SIgA 非添加時の附着数は 9 132個（44士26個）で

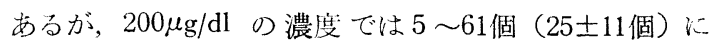
減少し, 健康成人女子に括汀る成績と比較するとその減 少の程度にも有意に大きな差が認められた. しかし下部
尿路感染症既往群の $200 \mu \mathrm{g} / \mathrm{dl}$ 添加時の附着数と健康成 人女子の SIgA 非添加時のそれを比較すると，な特前者 がやや多いことは注目すべきであろう。

一方 SIgA に上る細菌附着阻止作用の濃度依存性につ いてみると健康成人女子の上皮細胞の場合には Fig. 6 に見られる如く $100 \mu \mathrm{g} / \mathrm{dl}$ の濃度ではその作用が発揮さ れるものとそらでないものが認められた。 しかし 100 $\mu \mathrm{g} / \mathrm{dl}$ の濃度での E. coli 附着数と $200 \mu \mathrm{g} / \mathrm{dl}$ でのそれ を比較すると，附着数は後者の場合に有意に減少してい るものの, $200 \mu \mathrm{g} / \mathrm{dl}$ と $2,000 \mu \mathrm{g} / \mathrm{dl}$ の間には, 汪とんど 差を認めなかつた。一方下部尿路感染症群では $100 \mu \mathrm{g} / \mathrm{dl}$ の濃度に抢ける附着数の検討は行なつていないが，200 $\mu \mathrm{g} / \mathrm{dl}$ と $2,000 \mu \mathrm{g} / \mathrm{dl}$ の濃度間では附着数にはやはり大 きな差を認めなかつた。このことは各例によつて異なる ことは充分に推測されるところであるが，SIgA による 細菌附着阻止作用の発現にはある程度の高さの濃度（紼 菌附着阻止効果の発現濃度) の存在が必要であることを 示唆しているものと考えられた. この点を検討するため 患者から尿と膀胱粘膜の上皮細胞を同日時に採取し，尿 中 SIgA 濃度を測定すると其に in vitro で作成した 3 段階の SIgA 濃度 $(100,200,300 \mu \mathrm{g} / \mathrm{dl})$ に打ける附着 阻止作用を検討した.

その結果は Fig. 12 に見られる如く0〜>100 $\mu \mathrm{g} / \mathrm{dl} の$ 濃度であつた 4 例中 3 例では $100 \mu \mathrm{g} / \mathrm{dl}$ の試験管内濃度 で明らかな附着数の減少を認め, $100 〜<200 \mu \mathrm{g} / \mathrm{dl}$ の 4 例中 2 例は $200 \mu \mathrm{g} / \mathrm{dl}$ の試験管内濃度で, また $200 〜 300$ $\mu \mathrm{g} / \mathrm{dl}$ の尿中 SIgA 濃度が得られた 3 例中 2 例は 300 $\mu \mathrm{g} / \mathrm{dl}$ の試験管内濃度で附着阻止作用が認められた。 一方 $0 \sim>100 \mu \mathrm{g} / \mathrm{dl}$ 群の 1 例 (No. 3) は $300 \mu \mathrm{g} / \mathrm{dl}$ の試 験管内濃度でも附着数の減少は明らかでなかつたが, $100 \sim<200 \mu \mathrm{g} / \mathrm{dl}$ 群の 2 例 (No. 5, No. 6) 恃共に 300 $\mu \mathrm{g} / \mathrm{dl}$ の試験管内濃度では非添加時と比較すると附着数 は減少しているものと判断される. 以上の如く今回検討 した11例中 7 例は尿中濃度に相当寸る試験管内 SIgA 濃 度で明らかな附着阻止効果が認められ, 更に他の 2 例で も試験管内の SIgA 濃度を上げることにより, E. coli の上皮細胞への附着数の減少がみられた。尿中 SIgA 濃 度が採尿時間带の尿量や SIgA 雇生, 分泌の日内変動や 日差変動飞より大きく影響され得るものであることを考 慮するとSIgA の細菌附着阻止作用の効果発現濃度は非 感染時の尿中 SIgA 濃度附近にあるこが示唆されてい るものと解釈される.

尿路感染症のみならず他の感染症においても侵入微生 
物が粘膜に附着することは感染成立過程に执いて最も重 要な step であることは明らかである。近年細菌の細胞 への附着能を virulence の尺度として把えようとする 考兑かたも試みられ，またその機作についても検討さ れて来ている. M-protein ${ }^{32) 33)}$ や Lipoteichoic acid ${ }^{34}$ (Streptococcus), K-antigen ${ }^{35)}{ }^{36)}$ (E. coli) 等は比較的早 くから附着との関連が報告されて来たが，最近 $\mathrm{Ofek}^{377}$ 泣 mannose-specific antigen を, また Evans ら surface-associated colonization antigen を報告している. また細菌の表面構造としては pili39) 41), glycocalyx ${ }^{42)}$ 等が報告され，特に pili については附着との関連が強 調されているところである. 一方上皮細胞については, その表面に mannose-receptor が存在することは注注確 実視されているが3743)，他に Mycoplasma 汇対しては neuramic acid-receptor ${ }^{44)}$ ，V. cholerae に対しては fucose receptor ${ }^{45)}$ 等が存在するとする報告も見られる。一力 これら細菌と上皮細胞間の interaction についてみると Heckel ら ${ }^{46)}$ は両者の各々の表面は共に negative charged の状態で electrostatic barrier を形成しておらり,この状 態が崩壊した時に細菌は上皮細胞に附着するとし，その

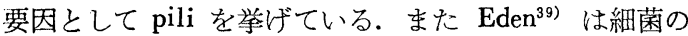
上皮細胞への附着には 2 段階めり，その第 1 段階は pili による可逆的な recognition phase であり，次いで細菌 および上皮細胞の specific な adhesive factor の cooperation により強固な static binding へと進み附着の 過程が完了するとしている.

現在までに明らかにされて来ているこのよらな機作の 中で SIgA がどのような部位に，どのような作用を拉 よぼしているかは未だ明らかではない，先の Williams $ら^{4)}$ は Streptococcus と buccal cell の interaction を娭 討した際 SIgA により㠜集する Streptococcus に対する SIgA の附着阻止作用は著明であるが，そうでないる のに対しては附着阻止作用も明らかでなからたとしてい る。また Gibbons ${ }^{47)}$ は彼の一連の実験成績から SIgA は 細菌の surface antigen と特異的に反応して凝集させる ことにより附着阻止作用を示すのであるうとしている。

一方 Eden ら ${ }^{48)}$ は，腎典腎炎尿中の specific SIgA を同 一患者の感染菌から抽出したO抗原で吸収すると SIgA の細菌附着阻止能が著明に低下することから SIgA は感 染菌のO抗原之特異的に反応して附着を阻止するのであ ろうとしている。これらはいずれも SIgA と細菌との間 には免疫学的汇特異な関係が存在することを指摘するも のであるが Parsons ら
細菌の surface protein が上皮細胞表面の reciprocally charged protein と反応（結合）することにより生ずる とし， SIgA はその際の細菌側の binding site を neutralyze することにより附着を阻止すると推測している。 今回著者らが用いた SIgA は健康成人女子尿から精 製したもので実験に供した E. coli $(0-148)$ に対して 非特異的であることは予備実験が示す通りである。しか し今回得られた著者らの成績では附着阻止作用が認めら れた。このことは SIgA の細菌附着阻止作用は必ずし も細菌汇対して SIgA が特異的である必要はないこと を示唆しているものと判断される. 先にも述べた如く Parsons $ら^{5)}$ は SIgA の細菌附着作用は細菌側の binding site をneutralyze することにより発揮されるであるう と指摘しているが，同時に SIgA の感染菌に対する特異 性は低く非感染時にその機能が発揮される性格であるう としている．この見解は今回得られた著者らの成績を解 釈するには，好都合であると共に，またもし SIgAが尿 路における感染防禦機構の中で機能するとすれば極めて 合目的的であるといえる. 更に膀胱に特沙る感染防禦機 構を理解する際にも興味のもたれるところである. 即ち 従来考えられて来た排尿による機械的な細菌排除機構も 感染防禦面ではあくまで第 2 義的なものであり，第 1 義 的には SIgA 等による侵入細菌の粘膜への附着阻止であ ろうと考觉らる。

一方このような細菌附着阻止作用が SIgA のみに特異 的なのか否かについてみると，Eden ら ${ }^{47)}$ は腎盂腎炎患 者尿中の IgG にも同様の作用が認められたとし，また Tramont ${ }^{49)}$ らも vaginal secretion 中の SIgA について 同様の報告をしている. 更に Steele ら ${ }^{23)}$ はV. cholerae のマウスに拈ける実験的腸管感染症に扔いて IgA， IgG 拉よび IgM のいずれもが細菌附着阻止能を有する可能 性を示している。しかしこれらの IgG および IgM は いずれも感染菌に対して反応した特異的なるのであり， 今回の実験に抢ける SIgA（非特異的）とは性格が異な る、そこで著者らは SIgA を分離した同一人の血清から IgG を分離し SIgA の場合と同様の方法で IgA の細菌 附着阻止能について検討した。 その表績は Fig. 13 に 見られる如く細菌附着阻止効果は明らかではなかつた。 Parsons $5^{5}$ は IgG は非感染時（即ち非特異的 IgG）に は細菌附着阻止作用を示さないとしているが，著者らの 成績もその推測を裏付けるものと云えよう。

\section{結語}

健康成人女子（15例）および下部尿路感染症の既往を 
有する成人女子 (30例) の膀胱粘膜 の上皮細胞を採取 し，これで急性単純性膀脂炎患者尿から分離した E. coli （０－148）を用いて附着実験を行ない，E. coli の上皮 細胞への附着におよぽす分泌型 IgA（SIgA）の作用を 検討し以下の成績を得た.

1）健康成人女子から 採取した上皮細胞では 1 個 の 上皮細胞につき $4 \sim 33$ 個（平均18個，正常範囲：7２9 個）の E. coli が附着し, SIgA を添加して $200 \mu \mathrm{g} / \mathrm{dl}$ の 濃度にした場合には E. coli 附着数は2〜25個（平均 14個，正常範囲：5２3個）に減少した.（減少率：22 $\%)$

2）下部尿路感染症の既往を有する女子から採取した 上皮細胞には, SIgA 非添加時 $9 \sim 132$ 個（Mean \pm 2 SD : $44 \pm 26$ 個）の E. coli が附着し, 健康成人女子に比較し て著明に多く，正常範囲の附着数を示したものは10例 （33.3\%）であつた. また附着数と下部尿路感染症（急 性単純膀脱炎）の既往頻度との関連についてみると，既 往頻度が高くなるに伴ない附着数も増加する傾向が認め られた。

一方 SIgA を添加して $200 \mu \mathrm{g} / \mathrm{dl}$ の濃度にした場合の 附着数は $5 \sim 61$ 個 (Mean $\pm 2 \mathrm{SD}: 25 \pm 11$ 個) に減少し たが, SIgA 添加時の正常範囲の附着数を示したものは 9 例 $(30.0 \%)$ であつた.

3）11例について尿中 SIgA 濃度を測定し，これに相 当する試験管内 SIgA 濃度での E. coli の細菌附着阻止 作用を検討した。 その結果 SIgA の細菌附着阻止作用の 発現頻度は非感染時の尿中 SIgA 濃度附近にあることが 推測された。

4）以上の成績から SIgA は少なくとも膀脱に括いて は侵入細菌の粘膜への附着を阻止する作用を有すること が推測され，またその作用は非特異的であつても発揮さ れる可能性が推測された.

稿を終えるにあたり実験成績の推計学的処理について 多大の御教示をいただいた市立砂川病院泌尿器科医長, 田宮高宏博士に深く感謝いたします。また種々の御協力 をいたたいいた教室員各位に深く感謝いたします。

本論文の要旨は第66回日本泌尿器科学会総会（昭和 53 年）に扔いて発表した。

\section{文献}

1) Tomasi, T.B. Jr. Tan, E.M., Solomon, A. and Prendergast, R.A.: Characteristics of an immune system common to certain external secretions. J. Exp. Med., 121, 101-125, 1965.
2) 西尾彰, 熊本悦明: 分泌 IgA 型に関する研 究 I. 各種尿路感染症に招汀る分泌型 IgA の 検討. 日泌尿会誌, 投稿中.

3) Arbuthnott, J.P. and Smyth, C.J.: Bacterial adhesion in host/Pathogen interactions in animals. in Adhesion of microorganisms to surfaces. Ellwood, D.C., Melling, J. and Putter, P., p. 165, Academic Press, New York, 1979.

4) Williams, R.C. and Gibbons, R.J.: Inhikition of bacterial adherence by secretory immunoglobulin A: a mechanism of antigen disposal. Science, 177, 697-699, 1972.

5) Parsons, C.L., Greenspan, C. and Mulholland, S.G.: The primary antibacterial defense mechanism of the bladder. Invest. Urol., 13, 72-76, 1975.

6) Parscns, C.L., Greenspan, C., Moore, S.W. and Mulholland, S.G.: Role of surface mucin in primary antibacterial defense of bladder. Urology, 9, 48-52, 1977.

7) Gibbons, R.J. and Houte, J.: Selective bacterial adherence to oral epithelial surfaces and its role as an ecological determinant. Infect. Immun., 3, 567-573, 1971.

8) 尾上蒸: DEAE-セルロースによるカラムクロ マトグラフィー：IgG の精製法. 免疫実験操作 法A. p. 129, 日本免疫学会編, 1975 .

9) Ebersole, J.L. and Molinari, J.A.: Specificity of secretory antibodies to bacterial immunogens. Infect. Immun., 13, 53-62, 1976.

10）木村義民：間接 赤血球凝集反応。臨免，4, 875-883, 1972.

11) King, D.W., Paulson, S.R., Puckett, N.L. and Krebs, A.T.: Cell death. IV. The effect of injury on the entrance of vital dye in Ehrlich tumor cells. Am. J. Path., 35, 1067-1079, 1959.

12) South, M.A., Cooper, M.D., Hong, R. and Good, R.A.: The IgA antibody system. Topic in developmental biology, 2, 191-222, 1967.

13）中尾 宁：ウイルス感染と局所兔疫. 臨小児医 学, 23, 231-240, 1975.

14) Ganguly, R. and Waldman, R.H.: Local immunity and local immune responses. Prog. Allergy, 27, 1-68, 1980.

15) Burdon, D.W.: The bactericidal action of immunoglobulin A. J. Med. Microbiol., 6, 131-139, 1973.

16) Hill, I.R. and Porter, P.: Studies of bactericidal activity to Escherichia coli of porcine serum and colostral immunoglobulins and the role of lysozyme with secretory IgA. Immunology, 
26, $1239-1250,1974$.

17) Adinolfi, M., Glynn, A.A., Lindsay, M. and Milne, C.M.: Serological properties of $\gamma \mathrm{A}$ antibodies to Escherichia coli present in human colostrum. Immunology, 10, 517-520, 1966.

18) Ishizaka, T., Ishizaka, K., Borsos, T. and Rapp, H.: C'l fixation by human isoagglutinins: Fixation of C'l by $\gamma \mathrm{G}$ and $\gamma \mathrm{M}$ but not by $\gamma \mathrm{A}$ antibody. J. Immunol., 97, 716-726, 1566.

19) Iida, K., Fujita, T., Inai, S., Sasaki, M., Kato, 'T. and Kobayashi, K.: Complement fixing abilities of IgA myeloma proteins and their fragments: The activation of complement through the classical pathway. Immunochemistry, 13, 747-752, 1976.

20) Götze, O. and Müller-Eberhard, H.J.: The C3-activator system: An alternate pathway of complement activation. J. Exp. Med., 134, Suppl., 90s-180s, 1971.

21) Wilson, I.D.: Studies on the opsonic activity of human secretory IgA using an in vitro phagocytosis system. J. Immunol., 108, 726-.. 730,1972

22) Zipursky, A., Brown, E.J. and Bienenstock, J.: Lack of opsonization potential of $11 \mathrm{~S}$ human secretory $\gamma$ A. Proc. Soc. Exp. Biol. Med., 142, $181-184,1973$.

23) Steele, E.J., Chaicumpa, W. and Rowley, D.: Isolation and biological properties of three classes of rabbit antibody to Vibrio cholerae. J. Infect. Dis., 130, 93-103, 1974.

24) Wernet, P., Breu, H., Knop, J. and Rowley, D.: Antibacterial action of specific IgA and transport of $\operatorname{IgM}, \operatorname{IgA}$ and $\operatorname{IgG}$ from serum into the small intestine. J. Infect. Dis., 124, 223-226, 1971.

25) Knop, J., Breu, H., Wernet, P. and Rowley, D.: The relative antibacterial efficiency of IgM, IgG and IgA from pig colostrum. Aust. J. Exp. Biol. Med. Sci., 49, 405-413, 1971.

26) Freter, R.: Studies of the mechanism of action of intestinal antibody in experimental cholera. Texas Reports on Bicl. Med., 27, Suppl., 1, 299-316, 1969.

27) Fubara, E.S. and Freter, R.: Protection against enteric bacterial infection by secretory IgA antibodies. J. Immunol., 111, 395-403, 1973.

28) Källenius, G. and Winberg, J.: Bacterial adherence to periurethral epithelial cells in girls prone to urinary-tract infections. Lancet. 1, 540-543, 1978.

29) Fowler, J.E. Jr. Stamey. T.A.: Studies of introital colonization in women with recurrent urinary infections. VII. The role of bacterial adherence. J. Urol., 117, 472-476, 1977.

30) Parsons, C.L. and Schmidt, J.D.: In vitro bacterial adherence to vaginal cells of normal and cystitis-prone women. J. Urol., 123, 184$187,1980$.

31) Stamey, T.A.: The portal of bacterial entry. in Urinary infections. Stamey, T.A., pp. 87123, The Williams \& Wilkins Co., Baltimore, 1974.

32) Ellen, R.P. and Gibbons, R.J.: $M$ proteinassociated adherence of Streptococcus pyogenes to epithelial surfaces: Prerequisite for virulence. Infect. Immun., 5, 826-830, 1972.

33) Ellen, R.P. and Gibbons, R.J.: Parameters affecting the adherence and tissue tropisms of Streptococcus pyogenes. Infect. Immun., 9, 85-91, 1974.

34) Ofek, I., Beachey, E.H., Jefferson, W. and Compbell, G.L.: Cell membrane-binding properties of group A Streptococcal lipoteichoic acid. J. Exp. Med., 141, 990-1003, 1975.

35) Wilson, M.R. and Hohmann, A.W.: Immunity to Escherichia coli in pigs: Adhesion of enteropathogenic Escherichia coli to isolated intestinal epithelial cells. Infect. Immun., 10, 776-782, 1974.

36) Uehling, D.T. and Balish, E.: Bacterial adherence to rat urothelium and $\mathrm{K}$-antigen content. in Infections of the Urinary Tract, Kass, D.H. and Brumfitt, W., p. 81, The University of Chicago Press, Chicago \& London, 1978.

37) Ofek, I., Beachey, E.H. and Sharon, N.: Surface surgars of animal cells as determinants of recognition in bacterial adherence. Trends Biochem. Sci., 3, 159-160, 1978.

38) Evans, D.G., Silver, R.P., Evans, D.J., Jr., Chase, D.G. and Gorbach, S.L.: Plasmidcontrolled colonization factor associated with virulence in Escherichia coli enterotoxigenic for humans. Infect. Immun., 12, 656-667, 1975.

39 Eden, C.S. and Hansson, H.A.: Escherichia coli pili as possible mediators of attachment to human urinary tract epithelial cells. Infect. Immun., 21, 229-237, 1978.

40) Silverblatt, F.J. and Ofek, I.: Effects of pili on susceptibility of Proteus mirabilis to phagocytosis and on adherence to bladder cells. in Infections of the Urinary Tract, Kass, E.H. and Brumfitt, W., p. 49, The University of Chicago Press, Chicago \& London, 1978. 
41) Fader, R.C., Avots-Avotins, A.E. and Davis, C.P.: Evidence for pili-mediated adherence of Klebsiella pneumoniae to rat bladder epithelial cells in vitro. Infect. Immun., 25, 729737, 1979.

42) Costerton, J.W., Geesey, G.G. and Cheng, K.J.: How bacteria stick. Scientific American. 238, 86-95, 1978.

43) Ofek, I., Mirelman, D. and Sharon, N.: Adherence of Escherichia coli to human mucosal cells mediated by mannose receptors. Nature, 265, 623-625, 1977.

44) Soberslavsky, P., Prescott, B. and Chanock, R.M.: Adsorption of mycoplasma pneumoniae to neuraminic acid receptors of various cells and possible role in virulence. J. Bact., 96, 695-705, 1968.

45) Jones, G.W. and Freter, R.: Adhesive properties of Vibrio cholerae: Nature of the interaction with isolated rabbit brush border membranes and human erythrocytes. Infect. Immun., 14, 240-245, 1976.

46 Heckels, J.E., Blackett, B., Everson, J.S. and Ward, M.E.: The influence of surface charge on the attachment of Neisseria gonorrhoeae to human cells. J. Gen. Microbiol., 96, 359-364, 1976.

47) Gibbons, R.J.: Bacterial adherence to mucosal surfaces and its inhibition by secretory antibodies. Adv. Exp. Med. Biol., 45, 315-325, 1974.

48) Eden, C.S. and Svennerholm, A.M.: Secretory immunoglobulin $\mathrm{A}$ and $\mathrm{G}$ antibcdies prevent adhesion of Escherichia coli to human urinary tract epithelial cells. Infect. Immun., 22, 790-797, 1978.

49) Tramont, E.C.: Inhibition of adherence of Neisseria gonorrhoeae by human genital secretions. J. Clin. Invest., 59, 117-124, 1977.

(1980年11月13日受付, 特別揭載) 